\title{
Key Tendencies of Osh Social Development in the XIX Century
}

\author{
Amanay T. Akmatova* \\ Osh State Law Institute \\ 40B Salieva Str., Osh, 723500, Kyrgyz Republic
}

Received 10.09.2014, received in revised form 11.12.2014, accepted 21.01.2015

The article describes regulatory functions of Osh city in the XIX century as it is this region that faced population development and exchange of material and intellectual values.

Keywords: administrative-territorial unit, political management, military outpost, volost, general governorate, tenor of life, district government, migration, tolerant existance.

Research area: history.

\section{Introduction}

After southern Kyrgyzstan joined Russia in 1876 the all-Russian system of administrative and political management was introduced on its territory. Osh, the oldest city, was chosen to be the uyezd (district) centre. The tsar's "organizers" wished Osh to be an important military supporting unit, an outpost of autocratic power in the south-eastern borders of the Russian Empire. Like all administrative and territorial units of Turkestan, Osh uyezd with its centre was under the jurisdiction of the Ministry of War, while Russian provinces were governed by the empire's Ministry of Internal Affairs. Osh uyezd initially consisted of Bulak-Bashi bekstvo and Osh serkerstvo. Much later they were replaced by the following volosts (territory ruled by the knyaz): Manyakskaya, Kashgar-Kishlakskaya, AkBuurinskaya, Kurshabskaya, Kapchigaiskaya, Gul'chinskaya, Alaiskaya, Turukskaya, and Naukatskaya.
According to the first general census of 1897 the population of Fergana region was 1572214 persons of both sexes, of which 852919 persons were males (54.2\%) and 719295 persons were females $(45.8 \%)$. The population of Osh uyezd was 161640 persons of both sexes, of which 85.785 persons were males and 75855 persons were females. In the city of Osh there lived 34157 persons of both sexes, of which 18306 persons were males and 15631 persons were females.

Thus, a distinguished feature of Fergana region was prevalence of males over females that was, in general, a characteristic feature of the New World states and annexed Central Asian regions. Fergana region's permanent population was nearly 1000 souls less than de facto population. Population inflow and outflow was insignificant. On the census day 813 persons were temporarily absent, 1784 persons were on their temporary residence. Fergana region's urban population number was $18.1 \%$ of the total population, such a

(C) Siberian Federal University. All rights reserved

* Corresponding author E-mail address: quelle-osh@mail.ru 
high value serving the index of the development of the local residents' factory and trading activities.

Osh got the status of Fergana region's uyezd centre. Major M.E. Ionov, M.D. Skobelev's associate, was appointed its head, lieutenant colonel P.G. Rodzyanko - its commandant. On March 10, 1876 the 4-th Turkestan combat maneuver battalion located in Osh. Its manpower was engaged in building barracks, warehouses and new houses during the whole spring and summer. It is a notable fact that the administrative apparatus was paramilitary the tsar's officers and uyezd officers ruling the regions and uyezds, and the heads of tribes and clans being the heads of the volosts. Thus, in 1876 M.D. Skobelev was appointed a Fergana region's military governor. In 1877 it was Abramov who was appointed a Fergana region's military governor. In 1877 Major Bachyrov was appointed a chief of Kokandsky uyezd. The chief of Osh uyezd in 1877 was Ivanov. In 1877 Aver'yanov was appointed a chief of Namangansky uyezd, Bekchurin was appointed a chief of Margilansky uyezd ${ }^{1}$.

The status of Osh as the uyezd centre significantly affected the urban life development. Compared to the times of Osh being the centre of Osh bekstvo and vilayet of Kokandsky khanate, its territories became twice larger. The structure of the city changed. Osh became a two-part city, including an old "native city" and a "new city", being the city's new part. The construction of the city's new part was directed by Modest Petrovich Rezvoy, a combat captain, who later strengthened the frontier posts in the restless Pamir-Alay. Staff-captain Sergey Andreevich Topornin, the first garrison commander, and M.E. Ionov, the first head of Osh uyezd, were directly involved in planning, original building and landscaping of a new uyezd center. This fact was noted by many Russian and foreign travellers who visited Osh in the XIX century. Thus, I.I. Geiner, a military officer, was one of the first to testify that there were two parts of the city - a native one and a Russian civilized one. He paid much attention to the description of the citizens' way of life ${ }^{2}$.

A.N. Kuropatkin, a Russian army officer, paid a great attention to the city of Osh in his reports. He studied the city's geographical location and climate, described its lands and population, noted the society's changing social structure, ethnic composition and different ethnic groups' belonging to religious movements, occupation, and age: “... the total number of the citizens engaged in agriculture was great and actually exceeded the traders' number. They were craftsmen and handicraftsmen. The wageworkers were not many" (Kuropatkin 1879).

P. Lunitsky, who visited Osh in the early XIX century, gives the following description of Osh in his book: "In the south-east corner of the Fergana Valley is Osh, a small ancient town, which was referred to by Chagatai chroniclers and other Asian travellers almost 1000 years ago. The city grew up at the intersection of large trade routes and was the place through which the Mongol khans and Chinese merchants brought their goods to the territory of modern Europe. Hordes of invaders also marched through it. Osh was a starting point for a caravan route to the Pamir Mountains. It is the place for the bases of Pamir expeditions. Our base was on the bank of the river Ak-Buura, in the house of Kuz'ma Yakovlevich Zherdenko, a local agronomist. We had to hire horses for our little caravan, buy sugar, rice, vegetables and other foods which could not be carried. We spent two weeks in Osh...”. During these two weeks the author observed the features of the city: "... there were a lot of soft cabs pulled by two horses, crowds of people thronged in the city, there was a brisk trade in the market, a brass band played in the park in the evening" (Lunitskii 1972).

An old "native" city was shabbily patronized by the authorities with the regards to the police 
and fiscal matters only but was still a centre of the local population's economic and spiritual life. For example, in 1882-1883 there were less than 50 houses and one hundred and fifty Russian citizens (except for the troops) in the new city. As for the old city, there were about 2800 houses and a few thousand inhabitants. There were 4 caravanserais and 852 small stores ${ }^{3}$.

The number of citizens increased. According to the first all-Russia census of the Russian Empire's population, in 1897 Osh uyezd was inhabited by 126689 Kyrgyz people, $65.8 \%$ of them were the settled. The report to the Governor General of Turkestan, dated July 4, 1898, stated the following population number:

Population number before the census after the census the Russians $\quad-1275 \quad 1650$ the natives $\quad-61089 \quad 157705$

Total: $\quad 62364 \quad 159355$

Compared to the population number before the census, the population number after the census increased in $155.5 \%$ [1.1.25.]. In Osh uyezd the population density per a verst (Russian unit of length) was 2.48. As for the urban population density in the total population of Kyrgyzstan, it was significantly lower than in the Russian Empire as a whole and this, in turn, reflected the position of the territory as one of the backward colonial outskirts of tsarism.

A multinational structure of the inhabitants of Osh was formed. Thus, according to the first general census in the Russian Empire, dated 1897, the Russians in Osh uyezd were 1 373, in Osh they were 989; the Poles in Osh uyezd were 191, in Osh they were 188; the Germans in Osh uyezd were 47, in Osh they were 45; the Tajiks in Osh uyezd were 107, all of them lived in Osh, the Jews in the city of Osh were 46, the Sarts in Osh uyezd were 571 , in Osh they were 8 , the TurkoTatars in Osh uyezd were 156 447, in Osh they were 32.432. As for the Russian subjects of the resident population in Osh uyezd, 85626 of them were males, 75845 of them were females. In Osh there lived 18348 males and 13641 females. As for those who temporarily arrived in Osh, the males were 153 , the females were 10 . As for foreign subjects, 5 males arrived in Osh (1 from China, 4 from Bukhara) $)^{4}$.

The most common specific feature of Osh in the XIX century characterizes it as a place of population concentration, the territory of industrial, cultural and town-planning potential. The territory of Osh was 2872 tithes and 1077 sazhens. The total area of 117 streets, 75 lanes, and 4 squares was 15 tithes and 1800 sazhens. The total length of streets and lanes was 1268 , the length of boulevards and streets, lined with trees, were 3 versts. The number of residential buildings in the Russian part of the city was 87 , whereas in the native part they were 6166 . There were no wooden houses in Osh, 3 houses were made of burnt bricks. The rest were made of adobe bricks. 25 houses were with iron roofs, other houses were roofed with reed (earth roofs). The water they used was from the Ak-Buur and the channels flowing from it. There was no sewerage. Impurities were taken to the fields, they were often disinfected, put into deep holes, which were 12 sazhens deep, and covered with earth ${ }^{5}$.

The tsar's authorities founded a new city, its "Russian part" being their military and colonial stronghold, along the Ak-Buur river and above the old town, housing a large market, a lot of little shops and wattle and daub houses, mosques outlined against their background. In addition to the uyezd management there was a postal telegraph office, a treasury and other establishments, various shops, shopping and buying offices of Russian and foreign companies, the estates of the officials, Russian merchants, businessmen and wealthy middle class. New types of legal enterprises, including barracks, churches and other military facilities, appeared in Osh. So, besides the state military building the 
city of Osh "has some adapted native structures, and last year (in 1896) an uyezd government, a prison and a post office were built" [1.1.10.]. Turkestan Gazette issue 51, 1898, informed us about the establishment of a temporary military court in the city of $\mathrm{Osh}^{6}$.

To the west of the fortress there appeared shopping districts and the upper market ("Tipsy Market"). By the end of the 70-s of the XIX century the initiative of M.E. Ionov, an uyezd chief, resulted in the construction of "own" market in order to buy products and household objects there. The uyezd authorities and the garrison's detached were interested in getting food for the officers and soldiers as well as fodder for the troop and draft horses right on the spot. Meanwhile, enterprising lieutenants did not even start buildig market small shops in the city's new part, bargaining currently favorable conditions. Besides, the city had neither money nor building materials. But M.E. Ionov was a person of sharp business wit. He found Mamata Itimov, a smart business contractor, among the townspeople, concluded a commercial contract with him on the $16^{\text {th }}$ of September, 1882, and a year later Mamata Itimov built 16 small shops which were leased out to the city merchants. 10 years later all new market's buildings and property became the property of the city (Sepernin 1920).

In the 90 -s of the XIX century a number of public buildings were constructed. These were a treasury, the military's club, a veterinary clinic (which is now Music School No. 2), a magistrate's court (which is now the municipal court of district 1), a notary public office (which is now a dwelling house), Filatov's shops (in the place of the oblast's current consumers association), Shchukin's shops (which are now post office No. 18 and "Odnazhdy" ("Once") café). Due to the abundance of landscape areas and water this part of the city looked pretty good. "There was a park, a garden, a concrete bridge across the Ak-Buura river (in the place between today's park named after Toktogul and the rest house). In the former park on the eastern bank of the river there is a groove of today's rest house, once owned by the Kokand dignitaries. A stone house for an uyezd dignitary was built on the hill"7.

The chief of Osh uyezd reported to the Governor General of Turkestan about the status of Osh uyezd on the $4^{\text {th }}$ of June, 1898: “... the main irrigation canal in the uyezd is the Ak-Buura river with its streams, flowing from the mountains and reaching SharikhanSai. 4 ditch aksakals supervise the irrigation system. 2110 rubles are paid to all of them from the community's fund. There are Mirabs in each society to help them. They are paid in kind. Whereas there is enough water in the lower part of the uyezd, its northern part lacks it especially when the rains are scant and atmospheric moisture is non-abundant. This situation is getting more disadvantageous with the growth of population and the development of agriculture. In 1895 it led to a petition on the extension of Sawai ditch, flowing from the Kara-Darya for 54 versts. The extension of the ditch it could make it possible to irrigate up to 11000 versts of land ${ }^{8}$.

One of the most important crafts in Osh was the construction of bridges. This was due to the developed system of artificial irrigation and numerous irrigation canals and ditches, crossing the roads. New bridges were erected, old bridges were repaired. There were nine operating bridges in Osh. Private houses, citadels, madrasahs, mosques, markets, etc. were being built on the city territory. This led to the need for architects and builders, which was evidenced by their impressive number. "Last year, in 1876 a road of two hundred versts was build from Osh to Gul'cha; three bridges were built on this distance, two of them over the river Gul'cha and one of them over the river Dzhimsa". 
On the $4^{\text {th }}$ of June, 1898 the chief of Osh uyezd reported to the Governor General of Turkestan that the amount of the duty paid in kind for fixing ditches was 260 rubles for horse workers (420 persons) and 2870 rubles for foot workers (7006 persons); materials (stone, wood, etc.) cost 1131 rubles and 20 kopecks. Total duty paid in kind in 1891 (if converted into money) was 14204 rubles and 45 kopecks. In 1898 they expected the amount of the duty paid in kind to be same ${ }^{10}$.

The report from June 4, 1898 by the chief of Osh uyezd to the Governor General of Turkestan stated the fact of unfavorable natural conditions, which affected the well-being of the national economy. The checkup committee, analyzing the economy of Osh neighborhoods, registered the results of that natural disaster: “... according to the collected data the loss of cattle due to a long lasting winter and spring starvation in the uyezd last winter and spring was the following: $650 \mathrm{rams}$, 6315 goats, 3677 horses, 4450 cows, 439 camels. The total number was 90236 heads that amounted to 310995 rubles on the average" ${ }^{\prime 1}$. Unfortunately, the committee did not report about any help to the population. The flood in Osh and its suburbs and the consequences of the Ak-Buura's flow for Naukatskaya and Bulak Bashinskaya volosts were also reported in Turkestan Gazette No. 39, 1987.

There was a strong contrast between the old ("native") part of the city and its new ("Russian") part built by the tsarist administration. Describing the city's old part, a Muslim newspaper "Waqt" (Time), published in Orenburg, wrote: "Like in many Turkestan cities the houses in Osh are built in a mess, its streets are narrow, rough and with many turns". The external character of the "native" city, inhabited by the indigenous population mainly, produced a painful impression with the blank walls of houses hiding poverty and despair. The length of the paves was negligible (three versts only). The length of sidewalks from gravel and pebbles and partly from brick was even less -1 verst only. The streets and quarters of the city's new part were built according to the military topographers' plan. The streets were straight and well landscaped there; rectangular blocks were divided into sections. Urban lifestyle with its inherent features and transport costs was the following. The means of communication in Osh in the XIX century were $11 \mathrm{cab}$ drivers. To get to the Russian part they had to pay 15 kopecks, whereas the cost for getting to the indigenous part was 40 kopecks. Such a significant difference in fare resulted not only from different distance to these parts. It was probably due to a difficult movement in the old town with lots of narrow and crooked alleys and dead ends, crowds of people in the places near the trading areas especially on Fridays and market days ${ }^{12}$.

On the $4^{\text {th }}$ of June, 1898 , the chief of Osh uyezd reported to the Governor General of Turkestan about the amount of the duty paid in kind for fixing the roads and constructions built on them. In 1897 the number of horse workers was 1101 persons, foot workers - 18371 persons. These amounted to 787 rubles and 75 kopecks for horse workers and 8640 rubles and 70 kopecks for foot workers. Materials delivered (gravel, sand, twigs, beams, boards, etc.) amounted to 563 rubles and 75 kopecks $^{13}$.

The city of Osh in the XIX century performed an administrative and charitable function. "There was one hotel, 11 taverns, 5 inns for local population (caravanserais) there. There were no homeless shelters there, but there were 2 common lodging houses for the local population. The number of charitable activities was 1 . One of Muslim schools had an almshouse for the cripples. The almshouse for the rich belonged to the mosque Asaf ibn Burhia. The Osh City Office kept the records of the disabled local population. Thus, the number of the blind from birth was 14 
males and 9 females; those who got blind were 12 males and 7 females; the deaf-and-numb were 2 ( 1 male and 1 female); the dumb were 5 females; the insane were 13 males and 1 female $^{14}$.

Osh hospital became the first military medical institution. Its staff provided medical assistance to the civilian population. In winter of 1877-1878 Osh military doctors (P. Devyatko and others) rescued Dungan rebels, who were wounded, sick and frostbitten, and the members of their families, who fled to the Russian territories after the defeat of their anti-feudal rebellion. In 1878 the newspaper "Golos" (Voice) published the article "The Occupation of Kashgar" in issue 13. The information in the article was about the occupation of Kashgar by the Chinese troops when more than 2000 Uighurs were forced to flee from the uyezd. Medical assistance was provided to Uighur refugees in Osh hospital No. 82. The first medical centers in Osh appeared in 1876. There were no health care sites for the indigenous population in Osh uyezd then. A military medic was the uyezd doctor. The chief of Osh uyezd in Fergana region reported on June 25, 1877: “... In Osh they designed a hospital ward with 6 beds for the natives. It made it possible to perform serious surgical operations. Thus, indigenous patients received health care in the uyezd doctor's apartment with 2 assistants, one being a native. As for public education, there were no Russian educational institutions in Osh uyezd. Native boys were taught to read in mosques and then got their further Muslim education in madrassas"15.

At the end of the XIX century "apart from a feldsher's station there was 1 hospital with 15 beds in Osh already. A doctor and his assistant took the patients (in 1899 the number of patients was 3070), vaccination against smallpox was performed by those whom they taught to do this. Daniil Vasil'evich Onushkevich was the first uyezd doctor, Georgii Iakovlevich Aushev was a dentist. Osh hospital occupied a small house where two adjacent communicating rooms served to be the wards"16.

On the basis of the Osh uyezd doctor's report to the military governor of Fergana region dated May 15, 1883 another clinic was opened in the city. It was for indigenous women. The report ran: “... Recently they have to deny proper medical benefits to some local residents of the region, especially to women. It is due to the lack of beds in the Osh hospital ward. This causes the need to apply for an increase in the number of beds up to 15 there" 17 .

Thus, the history of populating Kyrgyzstan and, in particular, the city of Osh serves the evidence of a "burst" of a new national element in the XIX century, the element being Russian immigrants with a specific outlook, culture, religion, and lifestyle. All this caused a natural need for a peaceful, tolerant coexistence of different cultures.

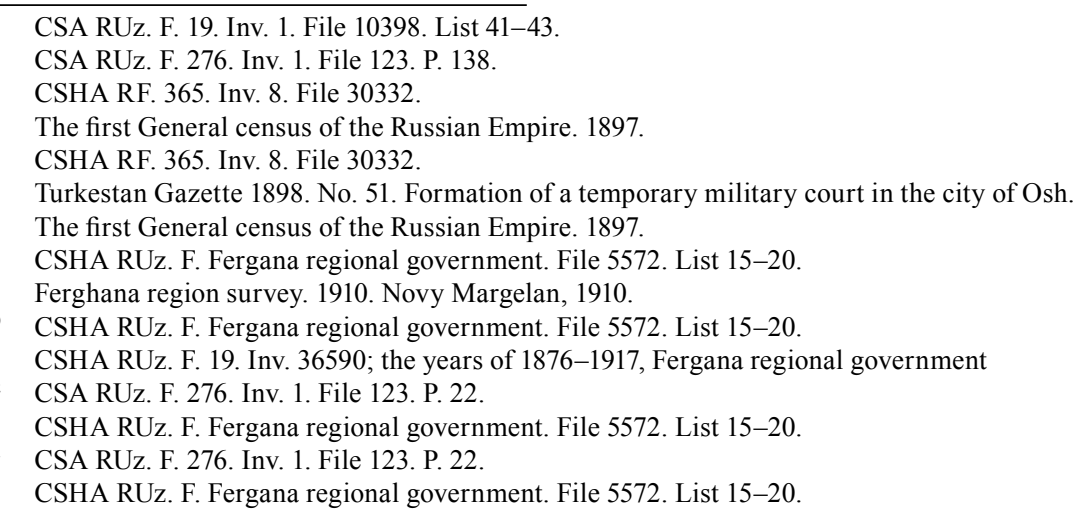


16 The report of an auditor by Imperial order (Turkestan Krai), privy councilor Girs. St. Petersburg, 1883.

17 Fergana region survey. The year of 1894. Novy Margelan, 1896.

\section{References}

1. Abytov B. K. Torgovo-ekonomicheskie otnosheniia goroda Osh i Fergany $v$ istoricheskoi perspective [Trade and economic relations of the city of Osh and Fergana in historical perspective]. Osh, 2000.

2. Alymbaev Zh. B. Obshchestvenno-politicheskaia zhizn' kyrgyzov v rossiiskoi istoriografii vtoroi poloviny XVIII - nachala XX vv. [Social and political life of the Kyrgyz people in the Russian historiography of the second half of the XVIII - beginning of the XX century]. Bishkek, 2009.

3. Babadzhanov B.M. Kokandskoe hanstvo: vlast', politika, religiia [Kokand khanate: power, politics, religion]. Tokyo; Tashkent, 2010.

4. Bartol'd V.V. Fergana. In: Sochineniia [Works]: 9 vol. Vol. III. Moscow, 1963b.

5. Bartol'd V.V. Istoriia kul'turnoi zhizni Turkestana [The history of the cultural life of Turkestan]. Frunze, 1963a.

6. Bernshtam A.N. Kul'tura drevnego Kyrgyzstana [The culture of ancient Kyrgyzstan]. Frunze, 1942.

7. Central State Archive of the Republic of Uzbekistan. F. 19. Inv. 1. File 10398. List 41-43.

8. Central State Archive of the Republic of Uzbekistan. F. 276. Inv. 1. File 123. P. 22

9. Central State Archive of the Republic of Uzbekistan. F. 276. Inv. 1. File 123. P. 22.

10. Central State Archive of the Republic of Uzbekistan. F. 276.Inv. 1. File 123. P. 138.

11. Central State Archive of the Republic of Uzbekistan. F. 19. Inv. 36590; the years of 18761917, Fergana regional government

12. Central State Historical Archive of the Republic of Uzbekistan. F. Fergana regional government. File 5572. List 15-20.

13. Central State Historical Archive of the Republic of Uzbekistan. F. Fergana regional government. File 5572. List 15-20.

14. Central State Historical Archive of the Republic of Uzbekistan. F. Fergana regional government. File 5572. List 15-20.

15. Central State Historical Archive of the Republic of Uzbekistan. F. Fergana regional government. File 5572. List 15-20.

16. Central State Historical Archive of the Russian Federation. 365. Inv. 8. File 30332.

17. Central State Historical Archive of the Russian Federation. 365. Inv. 8. File 30332.

18. Ferghana region survey. 1910. Novy Margelan, 1910.

19. Il'beikina M.I. (2012). Sovremennye muzeinye praktiki [Modern museum practices]. Modern problems of science and education, 1, 399.

20. Il'beikina M.I. (2013). Vizual'no-antropologicheskaia spetsifika sovremennykh kul'turnykh praktik [Visual and anthropological specificity of contemporary cultural practices]. Modern problems of science and education, 3, 452.

21. Karlova O.A., Koptseva N.P., Moskvich Iu.N., Kirko V.I., Reznikova K.V., Kolesnik M.A., Kistova A.V., Pimenova N.N., Viktoruk E.N., Viktoruk E.A., Shishatskii N.G., Pavlova I.P., Pavlov P.A., Nevzorov V.N., et al. Novoe budushchee Sibiri [The new future of Siberia]. Krasnojarsk, 2013. 
22. Kenensariev T. Sostoianie hoziaistva g. Osh i ego okrestnostei v kolonial'nyi period [The state of economy of Osh and its suburbs during the colonial period]. Osh, 2000.

23. Kirko V.I., Bukharov A.V., Keush A.V. (2010). Otsenka innovatsionnogo potentsiala tipovykh administrativno-territorial'nykh obrazovanii Krasnoiarskogo kraia [Estimation of the innovative potential of model administrative and territorial units of Krasnoyarsk Krai]. Innovatsii, 12, 78-83.

24. Kirko V.I., Zakharova K.N. (2013). Traditsionnaia hoziaistvennaia deiatel'nost' etnosokhraniaiushchii obraz zhizni [Traditional economic activity - ethno-preserved life style]. The Arctic and the North, 12, 24-31.

25. Kistova A.V. (2013a). Stanovlenie filosofii kul'tury kak metodologicheskoi osnovy gumanitarnogo znaniia [Formation of philosophy of culture as a methodological basis of humanitarian knowledge]. Modern problems of science and education, 1, 401.

26. Kistova A.V. (2013b). Etnograficheskii metod v sovremennykh kul'turnykh issledovaniiakh [Ethnographic method in contemporary cultural studies]. Modern problems of science and education, $6,900$.

27. Kolesnik M.A. (2014). Spetsifika ponimaniia slova "Rodina" studentami Sibirskogo federal'nogo universiteta [Specificity of understanding the word "motherland" by the students of Siberian Federal University]. Modern problems of science and education, 2, 648.

28. Koptseva N.P. Sovremennye kul'turnye praktiki sokhraneniia etnicheskoi identichnosti korennykh narodov Severa, Sibiri i Dal'nego Vostoka v Respublike Buriatiia [Modern cultural practices to preserve ethnic identity of northern, Siberian and Far Eastern indigenous peoples in the Republic of Buryatia] (2014). NB: Cultures and Arts, 1, pp. 17-30. doi: 10.7256/2306-1618.2014.1.10989.

29. Koptseva N.P. Vliianie sovremennykh kul'turnykh praktik na etnicheskuiu identichnost' korennykh malochislennykh narodov Tsentral'noi Sibiri [The influence of modern cultural practices on ethnic identity of indigenous peoples of Central Siberia] (2014). NB: Problemy obshchestva i politiki, 6, pp. 1-27. doi: 10.7256/2306-0158.2014.6.12201.

30. Koptseva N.P., Kirko V.I. (2014). Etnicheskie kharakteristiki i ikh analitika v sovremennykh kul'turnykh issledovaniiakh [Ethnic characteristics and analysis in contemporary cultural studies]. Modern problems of science and education, 3, 793.

31. Kuropatkin A.N. Kashgaria. Historical and geographical sketch of the country, its military industry, trade. St. Petersburg, 1879, III, 435 p. With a map of the northern part of Eastern Turkestan. Kyrgyz nomads from Osh to Kashgar. 222, 229,233, 234, 242, 247 p.

32. Libakova N.M. Modifikatsii gendernykh obrazov v rossiiskoi kul'ture kontsa XIX - nachala $X X I$ vv.: Dissertatsiia kandidata filosofskikh nauk. [Modifications of gender images in Russian culture of the late XIX - early XXI centuries: Thesis of candidate of philosophy]. Krasnoyarsk, 2011.

33. Libakova N.M., Sertakova E.A. Metodologiia prikladnykh etnologicheskikh issledovanii severnykh territorii Rossii: preimushchestva ekspertnogo interv'iu [Methodology of applied ethnological studies of northern territories of Russia: advantages of expert interviews] (2014). NB: Problemy obshchestva i politiki, 3, pp. 67-86. doi: 10.7256/2306-0158.2014.3.11268.

34. Lunitskii P. Selected works. Moscow, Khudozhestvennaya literatura, 1972.

35. Luzan V.S. Mekhanizmy vzaimodeistviia gosudarstva, biznesa s korennymi malochislennymi narodami Severa, Sibiri i Dal'nego Vostoka v usloviiakh global'nykh transformatsii [Interaction mechanisms of state and business with indigenous peoples of the North, Siberia and the Far East in

$$
-849-
$$


the context of global transformations] (2014). NB: Problemy obshchestva i politiki, 3, pp. 50-66. doi: 10.7256/2306-0158.2014.3.11297.

36. Luzan V.S. Sotsial'no-filosofskii analiz dinamiki gosudarstvennoi kul'turnoi politiki Rossiiskoi Federatsii: Dissertatsiia kandidata filosofskikh nauk [Socio-philosophical analysis of the dynamics of the state cultural policy in the Russian Federation: Thesis of candidate of philosophy]. Krasnoyarsk, 2011.

37. Pimenova N.N. Kul'turnoe nasledie korennykh malochislennykh narodov Krasnoiarskogo kraia i sovremennye kul'turnye praktiki [Cultural heritage of the indigenous peoples of Krasnoyarsk Krai and modern cultural practices] (2014). NB: Cultures and Arts, 2, pp. 28-66. doi: 10.7256/23061618.2014.2.11269.

38. Ploskikh V.M. Ocherki patriarkhal'no-feodal'nykh otnoshenii v Iuzhnoi Kirgizii $(50-70-e$ gody XIX v.) [Essays on patriarchal-feudal relations in southern Kyrgyzstan (50-70-s of the XIX century]. Frunze, Kyrgyzstan, 1968.

39. Ploskikh V.M. Starinnye rukopisi Chon-Alaia i Osha, vyiavlennye pervoi arkheograficheskoi ekspeditsiei. Istoriia, kul'tura i ekonomika iuga Kyrgyzstana [Codices of Chon-Alai and Osh discovered by the first archaeological expedition. History, culture and economy of southern Kyrgyzstan]. Osh, 2000 .

40. Ploskikh V.M., Dzholdosheva Zh. Kurmanzhan - alaiskaia tsaritsa [Kurmanjan, the Queen of Alai]. Bishkek, 2011.

41. Reznikova K.V. (2014). Immigratsionnaia politika zarubezhnykh stran: poisk priemlemykh modelei dlia Rossii [Immigration policy of foreign countries: search of acceptable models for Russia]. Modern problems of science and education, 2, 650.

42. Reznikova K.V. Sotsial'noe konstruirovanie obshchenatsional'noi identichnosti v Rossiiskoi Federatsii: Dissertatsiia kandidata filosofskikh nauk [Social design of national identity in the Russian Federation: Thesis of candidate of philosophy]. Krasnoyarsk, 2012.

43. Saparaliev D.B. uulu. Etnopoliticheskaia istoriia Osha i ego okrestnostei s XVIII do serediny $X I X$ veka [Ethno-political history of Osh and its suburbs from the XVIII to the mid-XIX century]. Bishkek, Ilim, 1999.

44. Semenova A.A. (2012). Vizual'naia kul'tura modernizirovannogo sotsiuma [Visual culture of the modernized society]. Science Journal of Volgograd State University. Series 7. Philosophy. Sociology and Social Technologies, 3, 145-149.

45. Semenova A.A. Modifikatsii drevnerusskogo kontsepta "gosudarstvo"v rossiiskoi kul'ture $X X I$ veka (metodologicheskii aspekt): Dissertatsiia kandidata filosofskikh nauk [Modifications of the Old Russian concept of "state" in the Russian culture of the XXI century: Methodological aspect: Thesis of candidate of philosophy]. Krasnoyarsk, 2009.

46. Sepernin F. (1920). Pages of history: Osh and the Osh residents. Mikhail Ionov. Leninskii put'.

47. Seredkina N.N. K voprosu o metodologicheskikh printsipakh kul'turno-semioticheskogo podkhoda v izuchenii iskusstva indigennykh narodov Severa, Sibiri i Dal'nego Vostoka [On the issue of methodological principles of cultural and semiotic approach to the research of the indigenous peoples of the North, Siberia and the Far East] (2014). NB: Cultures and Arts, 2, pp. 127-146. doi: 10.7256/23061618.2014.2.11320. 
48. Seredkina N.N. Konstruirovanie pozitivnoi etnicheskoi identichnosti v polikul'turnoi sisteme: Avtoreferat dissertatsii kandidata filosofskikh nauk [The construction of a positive ethnic identity in a multicultural system: Abstract of the thesis of candidate of philosophy]. Krasnoyarsk, 2013.

49. Sertakova E.A. (2012). Kul'turnaia geografiia A. Lefevra v svete gumanitarnykh issledovanii sotsial'nogo prostranstva goroda [A. Lefebvre's cultural geography in the context of humanity studies of the city social space]. Theory and Practice of Social Development, 3, 24-26.

50. Sertakova E.A. Kntsept "gorod" v russkoi kul'ture [The concept of "city" in Russian culture] (2014). NB: Cultures and Arts, 2, pp. 97-126. doi: 10.7256/2306-1618.2014.2.12044.

51. The first General census of the Russian Empire. 1897.

52. Turkestan Gazette 1898. No. 51. Formation of a temporary military court in the city of Osh.

53. Zamaraeva Iu.S. (2013). Vozmozhnosti sovremennykh kul'turnykh issledovanii dlia razvitiia teologicheskikh uchebnykh distsiplin v Rossiiskikh universitetakh [Possibilities of contemporary cultural studies for the development of theological disciplines in Russian universities]. Modern problems of science and education, 3, 413.

54. Zamaraeva Iu.S. (2014). Osobennosti sotsiokul'turnykh transformatsii migratsionnykh protsessov v XX - nachale XXI veka [Specific features of social and cultural transformations of migration processes in the XX - beginning of the XXI century]. Modern problems of science and education, 2, 649.

\section{Основные тенденции социального развития города Ош в XIX веке}

А.T. Акматова

Оиский государственный юридический институт Кыргызская Республика, 714018, Ош, ул. Салиева, 40в

\footnotetext{
В данной статье раскрываются регулятивные функиии города Ош в ХІХ веке, так как именно в этом регионе происходило движение населения, обмен материальных и интеллектуальных иенностей.

Ключевые слова: административно-территориальная единица, политическое управление, военно-опорный форпост, волость, генерал-губернаторство, уклад жизни, уездное управление, переселение, толерантное существование.
}

Научная спечиальность: 07.00.00 - исторические науки. 